\section{Intersections}

Canadian Journal of Music

Revue canadienne de musique
Intersections CANADIAN JOURAL OF MUSIO

\title{
Building Relationships, Sustaining Communities: Decolonial Directions in Higher Ed Bluegrass Pedagogy
}

\section{Travis D. Stimeling et Sophia M. Enriquez}

Volume 39, numéro 1, 2019

Decolonizing Music Pedagogies

URI : https://id.erudit.org/iderudit/1075342ar

DOI : https://doi.org/10.7202/1075342ar

Aller au sommaire du numéro

Éditeur(s)

Canadian University Music Society / Société de musique des universités canadiennes

ISSN

1918-512X (numérique)

Découvrir la revue

Citer cet article

Stimeling, T. D. \& Enriquez, S. M. (2019). Building Relationships, Sustaining Communities: Decolonial Directions in Higher Ed Bluegrass Pedagogy. Intersections, 39(1), 57-72. https://doi.org/10.7202/1075342ar
Résumé de l'article

Les récentes discussions sur la place de la musique bluegrass dans l'enseignement supérieur ont soulevé des inquiétudes quant au rôle historique que les établissements d'enseignement supérieur ont joué dans la colonisation, l'érosion et la destruction culturelles. Prenant pour exemple le groupe de bluegrass d'une grande université publique des Appalaches, cet essai examine comment le « bluegrass jam » pourrait faciliter des conversations utiles sur l'identité dans une région soumise à l'ascendance du style colonial depuis près de trois siècles. En même temps, cet article problématise la nature du soutien simultané de l'université à la culture régionale et à la propagation de l'extraction des ressources ainsi que de la dégradation de l'environnement.
(C) Canadian University Music Society / Société de musique des universités canadiennes, 2021
Ce document est protégé par la loi sur le droit d'auteur. L'utilisation des services d’Érudit (y compris la reproduction) est assujettie à sa politique d'utilisation que vous pouvez consulter en ligne.

https://apropos.erudit.org/fr/usagers/politique-dutilisation/ 


\title{
BUILDING RELATIONSHIPS, SUSTAINING COMMUNITIES: DECOLONIAL DIRECTIONS IN HIGHER ED BLUEGRASS PEDAGOGY
}

\author{
Travis D. Stimeling and Sophia M. Enriquez
}

In July 2017, essayist Ted Lehmann drew attention to bluegrass music's increasing presence in university curricula around the United States, calling upon directors and students of such programs to consider "whether going to college benefits students entering bluegrass programs and how it might affect the music itself." Suggesting that higher education's primary objectives are "to inform the past and to prepare workers for the future," Lehmann casts university bluegrass programs as inherently exploitative of students, culture bearers, and traditions. Numerous respondents challenged Lehmann's positions, highlighting the work that university-based scholars and practitioners do to expose students to new musical practices, guide aspiring musicians, and even critique prevailing norms of bluegrass culture. Perhaps most pointedly, Jocelyn Neal (2017) has argued that "bluegrass should go to college in all respects to take its place in the discourse and education of future generations of thinkers, artists, and leaders."

At the crux of Lehmann's concerns about university interests in bluegrass and old-time music, it seems, are anxieties about the historic role that institutions of higher education have played in cultural colonization, erosion, and destruction. ${ }^{1}$ As ethnomusicologist Mark DeWitt (2017) has noted, this is a typical concern for many higher education programs in traditional music: "Traditional music programs have a responsibility of conscious stewardship, lest they kill the very traditions they are trying to sustain. Mentors must allow students to find their own styles, nurture their creative voices within the traditions under study, and teach them to use any source material (whether it is a piece of sheet music or a recording) as just a starting point for learning a tune or song" (778). At the same time, as the 2014 College Music Society report "Transforming

1 The authors acknowledge that the terms "bluegrass" and "old-time" are thorny and difficult to define within the communities that practise them. For the purposes of this article and the program itself, "bluegrass" refers to the complex of commercial country music styles first associated with Bill Monroe, the Stanley Brothers, and Lester Flatt and Earl Scruggs, while "old-time" indicates the variety of string band styles associated with Appalachian contest and square dance fiddling and vocal styles associated with Appalachian balladry, gospel, and labour songs, among others (see Rockwell 2012; Reish 2017). 
Music Study from Its Foundations: A Manifesto for Progressive Change in the Undergraduate Preparation of Music Majors" suggested, many contemporary undergraduate programs in music reinforce an "ethnocentric orientation of music studies, which carries enormous societal ramifications. Once rectified, the resulting change opens important avenues of learning" (Campbell et al. 2016, 5). This article offers the possibility of decolonial Appalachian musical pedagogical practices. We emphasize how community relationships and what De Lissavoy names as a "pedagogy of lovingness" allow university-based bluegrass practitioners to build "an awareness of cultural difference while developing an enlarged solidarity that reaches beyond the local and the nation to participate in the construction of a global community" (De Lissavoy 2010, 288). Using examples from the bluegrass and old-time ensembles at a large Appalachian public university, this article considers how the "bluegrass jam" might facilitate meaningful conversations about identity in a region subjected to colonial-style extraction for nearly three centuries (see Lewis et al. 1978; Nyden 1979; Eller 2009). At the same time, this article problematizes the nature of the university's simultaneous support of regional culture and the propagation of resource extraction and environmental decay. Taken together, this article proposes that decolonial pedagogical practices are of the utmost importance in bluegrass and old-time music instruction, as such approaches necessarily work against the colonial tendencies of higher education institutions by not only foregrounding local knowledge, but also by allowing it to inform all aspects of pedagogy and by holding pedagogical practices and outcomes up for stakeholder scrutiny.

As a co-authorship, we bring two distinct perspectives and sets of experiences to this conversation about transgressive bluegrass pedagogy. We write together as a tenured professor who is responsible for the institutionalization and growth of bluegrass and old-time ensembles at West Virginia University (WVU) and a junior scholar who participated in the WVU Bluegrass and OldTime Bands as an undergraduate and is now working on a doctoral dissertation that explores Latinx communities and music-making in Appalachia. Our applications and theorizations of what decoloniality might mean for Appalachian music pedagogy is largely a result of extended conversations we have shared over the years that reject singular, monolithic narratives of Appalachian culture and push the limits of university-based learning. This collaboration might be thus positioned as a manifestation of a decolonial Appalachian musical praxis-one that empowers a young Chicana Appalachian studies scholar to engage critically with traditional forms and repertoires and the histories they index, while also encouraging a seasoned instructor descended from white settler-colonists in the region to challenge dominant narratives and to unsettle his own authority to create spaces within which students can connect meaningfully to a variety of regional traditions and histories. In this article and the practices that led to its writing, we interpret decoloniality as an iterative project with many possibilities, none of which are static, but all of which prioritize "submerged perspectives" (Gómez-Barris 2017, 1) and work toward 
the ultimate goal of decentring-and perhaps relinquishing-university control over these traditions.

\section{Contextualizing Bluegrass Pedagogy at West Virginia UNIVERSITY}

As Neal (2017) points out, bluegrass and old-time music have long associations with colleges and universities, whether as a subject of academic scholarship or as an object of musical practice. Although students frequently hosted bluegrass and old-time jam sessions as an extracurricular activity as early as the folk revival movement that flourished during the early 1960s (Rosenberg 1985, $154-8 ; 2018,124-9)$, the formalization of a bluegrass and old-time curriculum is a more recent phenomenon, emerging during the early 1980s with Jack Tottle's establishment of the Bluegrass, Old-Time, and Country Music program at East Tennessee State University and continuing through the work of the McLain Family (East Tennessee State Bluegrass, Old Time and Country Music Studies 2020; Jenkins 2020). More recently, degree programs at Hazard Technical and Community College (Kentucky), Glenville State College (West Virginia), and the Berklee School of Music (Massachusetts) have joined the fray, focusing their curricula on the development of essential skills for success within the bluegrass music industry, such as applied and ensemble study, harmony, songwriting, arranging, and recording. On its website in September 2019, the International Bluegrass Music Association (IBMA) listed seventy-five faculty members in Canada and the United States whose work involved teaching and studying these musics as practitioners and scholars (International Bluegrass Music Association 2018).

As with instructors of other "world music" ensembles (Solis 2004; Pedroza 2017; Talty 2017), bluegrass instructors often strike a fine balance between musical and cultural pedagogy. That is, instructors must determine how much of a premium is placed on musical performance and how much is placed on cultural competence. Particularly in music departments and schools of music, where musical performance is often deemed to be of paramount importance (Nettl 1995, 55-68), such demands often result in compromises between the ways that musical practices are taught within their traditional contexts and the ways that academic music departments teach music (the use of Western notation, for instance; see Riley 2017, 29-30). But, as is often the case, such compromises are not always visible to culture bearers within a particular musical tradition because geographic distance, cultural divisions, and financial restrictions often limit our abilities to connect our students with them, even if we bring those practitioners to campus from time to time. And, as Wangcaixuan (Rosa) Zhang $(2018,30)$ has recently observed, it may be necessary that instructors of world music ensembles begin "mindfully discussing and evaluating the colonial baggage of WMEs [world music ensembles] ... [as] a good entry point to begin deconstructing colonialist understandings." As ethnomusicologist and old-time musician Holly Riley has argued, "The methods and practices of old-time ensembles reflect unique features of their particular 
university settings and larger community contexts" (Riley 2017, 4), and bluegrass programs are no different.

The WVU Bluegrass and Old-Time Bands are housed in the WVU School of Music, one of three components of the university's College of Creative Arts (along with schools of theatre/dance and art/design). Offering undergraduate and graduate degrees in a number of specialties, the WVU School of Music has been the home of a World Music Performance Center since the early 1990s, when it formalized its pedagogical efforts in West African drumming and expanded to include gamelan, steel band, and taiko, among many other non-Western and vernacular musics. Bluegrass and old-time music instruction was first offered at WVU in 2014 using course numbers associated with these world music ensembles (initially "Chamber Music: Ethnic"). Now known as MUSC 363: Appalachian Music Ensemble, the course is open to all students enrolled at the university and typically attracts a substantial number of music majors (undergraduate and graduate) who are looking for new-tothem ways of making music, as well as students enrolled in other programs (particularly engineering and history) who bring some prior experience in the traditions to the course. As a consequence of a grant from the Foundation for Bluegrass Music, Inc., and generous private donations, students have access to a number of instruments at no expense to them, so students who are violin principals can develop experience on the mandolin, guitarists can take up the banjo, and students who do not have an instrument at all can borrow one of the university's instruments. Moreover, despite an enrolment cap of ten students per semester, the course is frequently over-enrolled as the result of student demand. As well, in the fall of 2018, an undergraduate minor in Appalachian Music began to be offered, adding introductory courses in music theory and Appalachian music and applied lessons (with classically trained musicians) to the ensemble course.

Ensemble instruction, in this case, works to accommodate the varying musical experience and technical mastery of the students in the course by creating multiple sub-ensembles that put experienced members in leadership positions. The instructor leads rehearsals for one hour each week; each ensemble is expected to rehearse for at least one additional hour on their own time, as well. Student bandleaders organize these additional rehearsals, much as section leaders might in a band, orchestra, or choir. During instructor-led rehearsals, each of the ensembles takes a turn performing their newest material or presenting a song that they would like assistance with. The instructor provides guidance on musical and stylistic concerns and offers insights into the cultural contexts of the music (for example, discussing the theological underpinnings of a song with roots in the Pentecostal traditions and connecting those frameworks to musical expression). At the same time, observing students are often called upon to offer critiques of the performances, creating a space in which everyone has the opportunity to take some degree of ownership away from the entire project.

Although students who are enrolled in the Appalachian Music minor must become fluent in Western notation, the group typically learns songs and tunes 
through oral/aural methods, either after witnessing a demonstration or listening to a recording; students also occasionally use the Nashville Number System, a shorthand system that uses Arabic numerals in place of more familiar Roman numerals or chord names) to outline the underlying harmonic progression and form of the song or a transcription to learn a fiddle tune (see Williams 2005; for extended discussion of the use of notation in these settings, consult Frank 2014, 65-9; DeWitt 2017, 78; Talty 2017, 107-8, 111-12). Rehearsals focus on ensemble coherence, arranging, style, and context, and a premium is placed on each student's individual growth. In fact, students submit monthly practice logs that document their practice and allow the instructor to provide additional resources (method books, recordings, technical tricks) to help students reach their own performance goals.

West Virginia University is one of two land-grant universities in the state, a federally defined classification for an institution of higher education that is obligated to serve the people of its state (initially through a focus on agriculture, engineering, military science, and classics) in exchange for taxpayer support and federal land holdings (Association of Public \& Land Grant Universities n.d.). The WVU Bluegrass and Old-Time Bands are therefore open to critique from community stakeholders and culture-bearers every time the group performs in public, and the group's most ardent supporters are often quick to provide the instructor with feedback on the musical performances of individual students, the entire ensemble, and the group's leader, as well as the group's repertoire, stage patter, and public image. As representatives of the state's largest land-grant institution, an institution that has often exhibited condescending attitudes toward the people it is chartered to serve, the WVU Bluegrass and Old-Time Bands must work diligently to respond constructively to these critiques, because they offer valuable insights into local ways of knowing and place the power of representation in the hands of the people being represented. Otherwise, the group risks replicating the same kind of colonial attitudes and practices that have characterized much world music instruction in the United States. At the same time, it is also worth noting that, for some members of the local and regional communities, the university's very presence in the bluegrass and old-time spaces is read as an important validation of these traditions.

\section{Theory: Why Decolonial Pedagogy?}

Proposing a decolonial bluegrass pedagogy that centres ground-level and community-oriented learning processes invokes a rich body of scholarship that considers the transgressive potential of applied decolonial practices (Mackinlay 2015). Although the emergence of post-colonial and decolonial studies in the 1980 and 1990 s paralleled a boom in higher education world music programs, attention to decoloniality as a guiding theoretical framework has been moving slowly in both Appalachian studies and ethnomusicology broadly. Still, contemporary writing on Appalachian music reflects a shift from more exclusionary performance practices and elite white dominant identities to the importance of grassroots and community-based music initiatives and efforts that 
specifically make space for queer people and people of colour (see, for example, the Shout and Shine Festival, Rhiannon Giddens's "Our Native Daughters" project, \#queergrass, and \#blackgirlbanjomagic) (see Thompson 2012; Baird 2018; Hausman 2018; Price 2018; Hight 2019). The work of expanding Appalachian music's reach to more diverse communities directly involves members of those communities. Establishing relationships with community members and efforts already in place prove crucial for the vast potential of decolonial work within Appalachian studies and world music studies. Our notion of decolonial bluegrass pedagogy fundamentally acknowledges that contesting claims of tradition and progress in Appalachian music have made space for few while silencing the voices of many. Decoloniality and decolonial pedagogy, then, are positioned here as a way to confront and rethink violent histories and, first and foremost, as a way for marginalized communities to create their own pedagogical and participatory musical space through collaboration. At WVU, collaboration has taken many forms, but perhaps none more powerful than the participation of students of colour, international students, and queer students in the program's activities.

The ideologies of decolonial pedagogy simultaneously disrupt assumptions about participatory music making and strengthen possibilities for space-making. In 2010, Noah De Lissovoy theorized a "curriculum against domination" that considers global systems of power and the ways in which decolonial thought might be leveraged to construct systems of education that evoke counter-narratives of global power. He also suggested a "pedagogy of lovingness" as an educational praxis that "builds local and global solidarities based on the principles of coexistence and kindredness" (De Lissovoy 2010, 280). Framing decolonial pedagogy in terms of both local and global social relationships lends itself well to concentrated, specific pedagogic practices (such as the one we focus on) and more comprehensive pedagogical models of world music. In both such instances, we suggest that the "pedagogy of lovingness" that De Lissovoy describes effectively and necessarily captures the spirit of relationality in Appalachian music-making.

Recent conversations in the fields of U.S. ethnomusicology and music education, too, have begun to explore the decolonial and relational possibilities of ethnographic research that centres indigeneity and indigenous epistemologies. Luis Chávez and Russell P. Skelchy (2019) have argued that "decolonization for music studies engages with 1 ) decentering western art music as the focus of music studies, 2) listening to and implementing indigenous and non-Eurocentric methodologies and knowledge systems, and 3) implementing decolonizing approaches in the classroom and in research practice" (118). During the "Indigenizing Ethnomusicology" roundtable discussion at the 2018 Society for Ethnomusicology meeting, for instance, discussants noted the ways in which indigeneity emphasizes teaching practices that centre relationships to sound, relationships between and among students and teachers, and relationships to land and place (Diamond et al .2018). We acknowledge that decolonial methods and pedagogies are not synonymous with scholarship that interrogates indigeneity as a response to violent histories of coloniality, and we make no 
claims to such distinctions. Rather, we consider that the multidimensional relationalities illuminated by the roundtable discussants provide an understanding of emergent ethnomusicological practices as very much focused on human interconnectedness. As a consequence, decolonial bluegrass pedagogy, as practised at WVU, deliberately and intentionally-although imperfectly-builds bridges between local communities of practice and university students in an effort to connect the program's work to the people and places who sustain it.

A bluegrass pedagogy that prioritizes relationality might most significantly gesture toward Appalachia's complex history of relationships to land and Appalachian residents' relationships to home and place. These relationships have been taken up fundamentally and extensively in Appalachian studies (see Reid 2005; Billings 2016, 61-2; Fisher and Smith 2016). The notion that Appalachia is an "internal colony" emerged in Harry M. Caudill's influential Night Comes to the Cumberlands $(1962,325)$ and was expanded by sociologist Helen Lewis during the 1970s to explain the impacts of extractive economies such as coal, oil, and natural gas development on the region and its people (see Lewis et al. 1978). Despite its value as a way to understand current economic and social challenges throughout parts of the region, though, the internal colony model typically ignores the role of the recently colonized in the colonization of Appalachian lands in the eighteenth century (Smith 2016, 73) and is "essentialistic ... in how it conceptualized the mountain South" (Billings and Blee 2000, 14). Most recently, Jacob L. Stump $(2018,154)$ offered a relational-decolonial framework for Appalachia by suggesting that "conceptualizing colonialism as a relationship (or set of relationships) between colonizer and colonized, where differences between self and other are rendered starkly unequal and open to intervention (in terms of health, education, religion, economy, political institutions, language, and dialect, etc.), serves to open up possibilities for empirical study and theorization." As such, even as the descendants of eighteenth-century colonists might find themselves subjected to industrial colonization, such a relational model allows us to view those same descendants as the beneficiaries of settler colonialism and challenges us to consider how effectively those descendants might be able to participate in decolonial projects.

Significant to the ways a decolonial bluegrass pedagogy might exist within structures of higher education-and specifically, the land grant institutionare the harmful legacies of physical and economic resources extraction from the Appalachian region that Stump gestures toward. In some ways, a model of bluegrass pedagogy like that of WVU's, which involves regular tours to public schools in the state, might implicitly resemble colonial power and activities of extraction. That is, West Virginia University might be seen as exploiting the traditional musical practices of its state's residents in an effort to appear more socially engaged than it is and to prove that, despite its entanglements with the coal, oil, natural gas, and timber industries, the university is generally committed to the welfare of all the state's residents. In fact, the university has regularly drawn attention to the work of the WVU Bluegrass and Old-Time Bands in its publicity materials, with the full support and cooperation of the ensemble's director, and the ensemble has sought donations to support the program 
through official university channels (see Mazzella 2016). Moreover, in a video piece used to introduce university president Gordon Gee's annual "State of the University" address, footage of the WVU Bluegrass and Old-Time Bands was presented with a voiceover arguing that "we are elevating Appalachian arts and culture in the context of our nation's history," fully articulating the colonial attitudes that are often reflected in the work of land grant universities (West Virginia University 2019).

A relational-decolonial pedagogic framework, however, allows for the resituating of colonialist models for public education into more intimate, community-focused spaces. In the case of bluegrass programs at institutions of higher education, intentional and personal relationships with local churches, public schools, and community service organizations not only acknowledge connections to land and place but serve the overall purpose of the public institution to return resources to, rather than extract from, local populations. Elizabeth Mackinlay $(2015,381)$, for instance, has challenged applied ethnomusicologists to accept the "response-ability of the ethnomusicologist, our capacity to respond to the call to decolonize" and has called for ethnomusicologists to question the presumed expertise of academics and to listen more carefully to the voices of the colonized. As she observes, "We have an ethical obligation to act on ... [our] wide awakeness to the ways in which we continue to 'be-in-relation' to colonialism" (392). That is, by constantly taking stock of the ways that our work is shaped by colonial attitudes and practices and by re-narrating our own implications as colonial actors, we can continue to refine our decolonial practice as we work with people in both intimate spaces and on large scales (393-4). In particular, the WVU Bluegrass and Old-Time Bands frequently perform in public schools around the state, focusing on rural and underserved schools that other WVU ensembles do not visit; only in rare instances does the program request travel assistance from the schools that it visits, instead relying primarily on donations and occasional paid performances for university events for financial support, a practice that is intended to alleviate the financial pressures on the program's hosts. In these public school concerts, university students perform music from the region as well as occasional bluegrass covers of contemporary popular songs, while the director shares stories about the historical contexts of the music and invokes the names of local practitioners of these styles. For example, a performance in Monongalia County, where WVU is located, might include a discussion of beloved local fiddler Elmer Rich, while a performance in the southern coalfield community of Matewan might include a discussion of the music's connections to the local labour movement and the historic "mine wars" that took place there in the early twentieth century. Through this work, then, the WVU Bluegrass and Old-Time Bands reinforce the value of local musical practices and to provide cultural education that is grounded not in grand narratives but in the nuances of local history and lore. At the same time, using storytelling as a decolonial tool allows for the mobilization of lived experiences and stories toward the project of decoloniality, reimagining the narratives of Appalachia's white settler colonial history embedded in bluegrass music as a way to prompt reflection and critical 
conversation that challenges the very performance traditions from which they come (see Teves 2018, 113-45).

Another important way that the WVU Bluegrass and Old-Time Bands cultivate decoloniality through relationships is in jam sessions, whether during in-class jams or within the community. Many bluegrass and old-time music programs encourage students to participate in jam sessions, and the WVU program is no different (see Titon 2009, 122; Riley 2017, 41-5). Participation in local jam sessions, we argue, is vital to decolonial practice, as it affords students a wide range of hands-on experiences with the musical styles they are studying in an academic performance setting within the contexts in which it is typically performed and with the people to whom these traditions matter the most. At the same time, it provides an opportunity for members of local jam sessions to serve as mentors to aspiring musicians and to create opportunities for dialogue about important community issues.

Bluegrass and old-time jam sessions typically take place within circles, which provide a convenient metaphor for thinking about decolonial pedagogy in praxis. Specifically, the jam circle offers a critical lens through which to view the socio-spatial politics of inclusion. Decolonial practice necessarily critiques the jam circle resemblance of a physical margins-centre model. The structure of a jam involves musicians who are seated or standing in a circle, at once implying physical access granted to those considered a part of the circle and the liminality of those outside the circle. The structure of the jam circle also suggests a coherent, bound, unified performance practice. Jams that develop localized practices, such as a distinct bodily gesture, that signal musicians to end a song, however, push against this suggestion. In this way, the bluegrass and old-time jam circle is a set of paradoxes, simultaneously suggesting coherence and flexibility, inclusion and exclusion, and participation and preclusion.

Thomas Turino, in his extensive writing on "musical participation," frequently points to old-time jams as a particularly vibrant site for the exploration of participation as both a musical and social phenomenon (Turino 2008, $155-88$; 2018). Reflecting on nearly five decades of participation in old-time musicking, Turino notes that old-time string band music is commonly performed and transmitted within the context of the jam session. But, unlike jam sessions in other contexts (such as jazz) where the jam may be a site to demonstrate one's prowess over other participating musicians, "events designated as jams are participatory by nature, and ostensibly, anyone at any skill level is welcome" $(2018,23)$. As such, old-time jams frequently come close to Turino's ideal form of participation in which everyone "contribut[es] to the sound and motion of a musical event through dancing, singing, clapping, and playing musical instruments when each of these activities is considered integral to the performance" $(2008,28)$. Or, as Turino has suggested more recently, truly participatory performances occur "when all contributions are deemed valuable, indeed necessary, for the success of the performance" $(2018,18)$. It is this sense of participatory performance that is particularly potent for the decolonization of bluegrass and old-time pedagogy. Bluegrass and old-time jam sessions require everyone to participate in their own particular way, and a jam's success 
or failure is often determined not only by the quality of the musicianship, but by the quality of the social fellowship between tunes and between jam sessions. It is through these social interactions that jam sessions become places where local and regional knowledge can be transmitted: local and regional repertoires and styles are demonstrated and learned (24); stories about locally and regionally significant musicians are shared; and musical networks are established and reinforced. As such, the jam session is a space in which the tradition can be sustained (Schippers 2016; Grant 2016) in a manner that is already well established and maintained by its practitioners. But, as Riley $(2017,41-5)$ notes, jam sessions often differ from ensemble rehearsals in substantive ways, and the sociocultural differences between those settings might discourage students from participating in the local jam community.

To help students navigate the jam session environment successfully, students in the WVU Bluegrass and Old-Time Bands are expected to participate in a local jam session at least once each month. Jam sessions are held in a variety of venues around town, from local cafes and night spots to academic buildings on the WVU campus. Each of these jam sessions maintains its own distinct characteristics, even as individual musicians occasionally move freely among them. One jam session, for instance, is particularly welcoming of new musicians, playing tunes at slow to moderate tempos and encouraging newcomers to join the main group, while another session typically includes highly experienced musicians who prefer to play at brisker tempos. Some jam sessions favour fiddle tunes, while others prefer bluegrass songs. Students are provided a number of options, then, to allow them to fit a session into their busy schedules, to find a space in which they feel safe to participate (as defined by many factors), and to work with a community that challenges them musically.

At the beginning of each semester, students are provided with a list of regular jam sessions in the community, along with a short, but vital "community engagement" assignment. In this assignment, students are required to provide photographic evidence of their active participation (i.e., a "selfie" with their instrument in hand) and a brief response to two questions: 1 ) What did you learn musically from your participation in the jam? and 2) What did you learn about the community from your participation in the jam? These responses are submitted to the instructor via email shortly after the jam session to document their participation; the instructor also offers brief feedback on their work, sometimes taking the form of encouragement ("I'm proud of you for taking the chance to lead a tune!") or further recommendations ("If you like the way they do that song, you might want to listen to this recording"). As students continue to participate in the WVU ensembles over successive semesters, they often feel deeply imbricated within the local musical community and provide guidance for less experienced students who are participating for the first time. These assignments allow students to situate themselves as part of a local community beyond the walls of the university. The relationships formed by community engagement assignments allow both out-of-state and in-state students to nourish relationships with local musicians who often afford them performance opportunities outside of the university setting while also equipping them with knowledge and skills 
in regional musical practices (see De Lissovoy 2010). Especially for music education majors, this allows for a higher level of cultural competence in student teaching placements and regional job placements. Because of such entrances into bluegrass and old-time communities in Morgantown, West Virginia, several students have since gone on to form their own groups that perform a variety of folk music traditions across the Appalachian region and the globe.

Community engagement decentres the instructor and formal instruction, yet another useful tool in the decolonization of bluegrass pedagogy (cf. Chávez and Skelchy 2019). Because these jam sessions create spaces for students and community members to get to know one another through a shared interest in bluegrass and old-time music, pedagogical relationships are often formed between students and local musicians, whether through the informal passing of tunes and techniques from one to another or through more formal mechanisms. In fact, some students in the ensemble have sought out local musicians for formal lessons and have brought their newfound expertise to bear during ensemble rehearsals by teaching repertoire and techniques to other ensemble members. Moreover, the instructor does not usually participate in these community jam sessions, allowing them to be spaces in which the authority of the instructor is not present and creating the possibility for students to take more direct ownership over their own learning. As such, the knowledge of the local community is foregrounded in these settings, and it comes to shape the activities that unfold within ensemble rehearsals and performances.

Nevertheless, we note the potential limitations of the jam session as a decolonial space. As Helen O'Shea $(2006-7,1)$ has remarked in her ethnographic study of Irish traditional music sessions, "Expectations of musical community, and claims to have located it, are common to scholarly and popular narratives about music of many genres and locations-cathartic narratives that begin with the beauty of the rainbow and end with an eloquent account of the golden booty it yields." She notes especially that "newcomers" and interlopers (as these students certainly are at the beginning of their journeys) can be seen as diminishing the quality of the sessions (7) and may lead "many of the highest-status musicians [to] avoid playing in public sessions (10). Moreover, O'Shea observes, the entire notion of "local" is often complicated by the presence of musicians who travel from neighbouring communities or visit from other parts of the world to participate in the session (7-8). These factors are most certainly at work in the community that the WVU Bluegrass and Old-Time Bands' students engage with. "Local" jam session participants sometimes drive more than two hours roundtrip each week, and several of the most celebrated musicians in the community do not participate in the jam scene. Further ethnographic engagement with the dynamics of the jam sessions that WVU students participate in will be necessary to determine the success or failure of these particular decolonial efforts.

\section{Conclusion: Applied Trajectories}

As evidence of the decolonial pedagogic practices put forth here, students often describe feeling deeper connections to place and a commitment to building 
lives in West Virginia upon graduation after visiting schools throughout the state, helping to reverse the "brain drain" that has commonly been associated with attainment of higher education in rural areas (Sherman and Sage 2011). Furthermore, through regular engagements with individuals at jam sessions, students are able to learn the textures of places and the communities that call them home, to develop an understanding of the dynamics of local life, and to cultivate a respect for the individual and the community that ultimately resists exploitation. This connectivity, however, also reflects the tension of what it means to decolonize Appalachian music: the ability of bluegrass to foster global understanding and build more inclusive communities is problematized by its inherent connection to perpetually abusive and disenfranchising institutional models at the local, state, and national levels. Transgressive bluegrass pedagogy may be appropriately limited by histories of indigenous erasure for which the narrative of Anglo-Appalachian music-making is a painful reminder. A nuanced decolonial model of music learning that centres relationality, practises reflexivity, works towards inclusivity, and teaches the music of Indigenous, Black, Latinx, and other historically racialized groups in Appalachia will never be enough to rectify the damage caused by centuries of settler colonialism.

Despite these limitations and tensions, and perhaps because of them, we believe that a decolonial pedagogy of bluegrass and old-time music has great potential to support the creation of more just, equitable, and inclusive environments within the Appalachian region and beyond. The decolonial direction of bluegrass pedagogy deliberately invites people from different backgrounds to come together around a shared project while decentring the instructor's expertise and allowing for greater collective ownership of the work. It critiques conventional narratives and makes those critiques concrete through collaboration, dialogue, and direct action. It seeks out the palimpsests left behind as a result of colonial cultural erasure and amplifies the voices of people who have been silenced. And, within the context of a land-grant institution, it shifts institutional power away from faculty and administrators who might have good intentions but competing priorities and places it in the hands of the very students whose future well-being is often threatened by the neo-liberal attitudes and practices in higher education.

\section{REFERENCES}

Association of Public \& Land-Grant Universities. n.d. "Land-Grant University FAQ." https://www.aplu.org/about-us/history-of-aplu/ what-is-a-land-grant-university/.

Averill, Gage. 2004. "Where's "One"?': Musical Encounters of the Ensemble Kind." In Performing Ethnomusicology: Teaching and Representation in World Music Ensembles, edited by Ted Solís, 93-111. Berkeley: University of California Press.

Baird, Sarah. 2018. "Appalachia Has a Booming Hispanic Population-and Its Growing Food Scene Is Making an Impact." Mic, 27 July. https://www. mic.com/articles/190452/appalachia-has-a-booming-hispanic-populationand-its-growing-food-scene-is-making-an-impact. 
Billings, Dwight B. 2016. "Rethinking Class beyond Colonialism." Journal of Appalachian Studies 22 (1): 57-64.

Billings, Dwight B., and Kathleen M. Blee. 20oo. The Road to Poverty: The Making of Wealth and Hardship in Appalachia. Cambridge: Cambridge University Press.

Bohlman, Philip V. 2006. "On Cosmopolitanism: Our Journeys with Others." SEM Newsletter 40 (2): 4-5.

Campbell, Patricia Shehan, David Myers, and Ed Sarath. 2014. “Transforming Music Study from Its Foundations: A Manifesto for Progressive Change in the Undergraduate Preparation of Music." College Music Society. https:// www.music.org/pdf/pubs/tfumm/TFUMM.pdf. Copyedited 2016.

Caudill, Harry M. 1962. Night Comes to the Cumberlands: A Biography of a Forgotten Area. New York: Atlantic Monthly.

Chávez, Luis, and Russell P. Skelchy. 2019. "Decolonization for Ethnomusicology and Music Studies in Higher Education." Action, Criticism, and Theory for Music Education 18 (3): 115-43.

De Lissovoy, Noah. 2010. "Decolonial Pedagogy and the Ethics of the Global." Discourse: Studies in the Cultural Politics of Education 31 (3): 279-93.

DeWitt, Mark F. 2017. "Training in Local Oral Traditions: Analysis of Postsecondary Music Programs in North America." In College Music Curricula for a New Century, edited by Robin D. Moore, 69-97. New York: Oxford University Press.

Diamond, Beverley, Jessica Bissett Perea, Trevor Reed, Amber Ridington, John-Carlos Perea, Keola Donaghy, and Stephen Fox. 2018. "Indigenizing Ethnomusicology: Histories, Theories, and Methods." Panel presented at 63rd Annual Meeting of the Society for Ethnomusicology, Albuquerque, NM, 16 November.

East Tennessee State University Bluegrass, Old Time, and Country Music Studies. 2020. "History." https://www.etsu.edu/cas/das/bluegrass/about-us/history.php.

Eller, Ronald D. 2009. Uneven Ground: Appalachia since 1945. Lexington: University Press of Kentucky.

Fisher, Steve, and Barbara Ellen Smith. 2016. "Internal Colony-Are You Sure? Defining, Theorizing, Organizing Appalachia." Journal of Appalachian Studies 22 (1): 45-50.

Frank, Alexandra. 2014. “That's the Way I've Always Learned': The Transmission of Traditional Music in Higher Education." MA thesis, East Tennessee State University. https://dc.etsu.edu/cgi/viewcontent. cgi?article $=3743 \&$ context $=$ etd.

Gómez-Barris, Macarena. 2017. The Extractive Zone: Social Ecologies and Decolonial Perspectives. Durham, NC: Duke University Press.

Grant, Catherine. 2016. "Music Sustainabilities: Strategies and Interventions." In Sustainable Futures for Music Cultures: An Ecological Perspective, edited by Huib Schippers and Catherine Grant, 19-42. New York: Oxford University Press. 
Hausman, Sandy. 2018. "Che Apalache Hopes to Open Minds and Ears with Their Latin Bluegrass Fusion.” National Public Radio, 14 August. https:// www.npr.org/2018/08/14/638629428/che-apalache-hopes-to-open-mindsand-ears-with-their-latin-bluegrass-fusion.

Hight, Jewly. 2019. "'Songs of Our Native Daughters' Lays Out a Crucial, Updated Framework for Americana." National Public Radio, 14 February. https://www.npr.org/2019/02/14/693624881/ first-listen-our-native-daughters-songs-of-our-native-daughters.

International Bluegrass Music Association. 2018. "Bluegrass College Programs (08.2018 update)." Accessed 26 September 2019. https://docs. google.com/spreadsheets/d/1yWSYbxModDpNKPQbQy1m87Z4alrwkTEzu8eb1-cgRds/edit\#gid=0.

Jenkins, Paul O. 2020. Bluegrass Ambassadors: The McLain Family Band in Appalachia and the World. Morgantown: West Virginia University Press.

Lehmann, Ted. 2017. "Bluegrass Goes to College, But Should It?" No Depression, 5 July. https://www.nodepression.com/ bluegrass-goes-to-college-but-should-it/.

Lewis, Helen M., Linda Johnson, and Donald Askins, eds. 1978. Colonialism in Modern America: The Appalachian Case. Boone, NC: Appalachian Consortium.

Mackinlay, Elizabeth. 2015. The Oxford Handbook of Applied Ethnomusicology. Edited by Svanibor Pettan and Jeff Todd Titon, 379-97. New York: Oxford University Press.

Mazzella, Diana. 2016. "At the Twilight: Keeping Appalachian Music Alive." WVU Magazine (Fall). https://magazine.wvu.edu/stories/2016/11/04/ at-the-twilight-keeping-appalachian-music-alive.

Morris, Christine Marie. 1995. "Roots, Branches, Blossoms, and Briars: Cultural Colonialism of the Mountain Arts in West Virginia." PhD diss., Pennsylvania State University.

Neal, Jocelyn. 2017. "Should Bluegrass Go to College? Yes." OUP Blog, 16 September. https://blog.oup.com/2017/og/reflections-on-country-and-bluegrass/.

Nettl, Bruno. 1995. Heartland Excursions: Ethnomusicological Reflections on Schools of Music. Urbana: University of Illinois Press.

Nyden, Paul J. 1979. "An Internal Colony: Labor Conflict and Capitalism in Appalachian Coal." Insurgent Sociologist 8 (4): 33-43.

O'Shea, Helen. 2006-7. "Getting to the Heart of the Music: Idealizing Musical Community and Irish Traditional Music Sessions." Journal of the Society for Musicology in Ireland 2:1-18.

Pedroza, Ludim. 2017. "Latin Music Ensembles at Texas State University: The Undergraduate Minor in Mariachi and Its Implications for Expansive Curricula in Mainstream Institutions of the United States." In College Music Curricula for a New Century, edited by Robin D. Moore, 135-54. New York: Oxford University Press.

Price, Elizabeth. 2018. "Homegrown Black Metal Smashes Stereotypical Appalachian Narratives." 100 Days in Appalachia, 21 April. https://www.10odaysinappalachia.com/2018/04/21/ 
homegrown-black-metal-smashes-stereotypical-appalachian-narratives/.

Reid, Herbert G. 2005. "Appalachia and the 'Sacrament of Co-existence': Beyond Post-colonial Trauma and Regional Identity Traps." Journal of Appalachian Studies 11 (1/2): 164-81.

Reish, Gregory N. 2017. "On the Notion of 'Old-Time' in Country Music." In The Oxford Handbook of Country Music, edited by Travis D. Stimeling, 117-40. New York: Oxford University Press.

Riley, Holly Bugg. 2017. "Community in the Academy: Musicianship and Transformation in University Old Time Ensembles and Local Music Scenes." MA thesis, Florida State University.

Rockwell, Joti. 2012. "What Is Bluegrass Anyway? Category Formation, Debate and the Framing of Musical Genre." Popular Music 31 (3): 363-81.

Rosenberg, Neil V. 1985. Bluegrass: A History. Urbana: University of Illinois Press.

-2018. Bluegrass Generation: A Memoir. Urbana: University of Illinois Press.

Schippers, Huib. 2016. "Sound Futures: Exploring the Ecology of Music Sustainability." In Sustainable Futures for Music Cultures: An Ecological Perspective, edited by Huib Schippers and Catherine Grant, 1-18. New York: Oxford University Press.

Sherman, Jennifer, and Rayna Sage. 2011. "Sending Off All Your Good Treasures: Rural Schools, Brain-Drain, and Community Survival in the Wake of Economic Collapse." Journal of Research in Rural Education 26 (January): $1-14$.

Smith, Ada. 2016. “Appalachian Futurism.” Journal of Appalachian Studies 22 (1): $73-5$.

Solis, Ted., ed. 2004. Performing Ethnomusicology: Teaching and Representation in World Music Ensembles. Berkeley: University of California Press.

Stump, Jacob L. 2018. "What Is the Use of the Colonial Model (or, Better Yet, the Concept of Coloniality) for Studying Appalachia?" Journal of Appalachian Studies 24 (2): 151-67.

Talty, Jack. 2017. "Noncanonical Pedagogies for Noncanonical Musics: Observations on Selected Programs in Folk, Traditional, World, and Popular Musics." In College Music Curricula for a New Century, edited by Robin D. Moore, 101-14. New York: Oxford University Press.

Teves, Stephanie Nohelani. 2018. Defiant Indigeneity: The Politics of Hawaiian Performance. Chapel Hill: University of North Carolina Press.

Thompson, Deborah J. 2012. "Performing Community: The Place of Music, Race and Gender in Producing Appalachian Space." PhD diss., University of Kentucky.

Titon, Jeff Todd. 2009. "Teaching Blues and Country Music, and Leading an Old-Time String Band-at an Ivy League University." Journal of Popular Music Studies 21 (1): 113-24.

Turino, Thomas. 2008. Music as Social Life. Chicago: University of Chicago Press. 
. 2018. "Participatory Performance and the Authenticity of Place in OldTime Music." In The Routledge Companion to the Study of Local Musicking, edited by Suzel A. Reily and Katherine Brucher, 17-28. New York: Routledge.

West Virginia University. 2019. "State of the University Address-March 2019." https://presidentgee.wvu.edu/speeches/ state-of-the-university-address-march-2019.

Williams, Chas. 2005. The Nashville Number System. Nashville, TN: Nashville Number System.

Zhang, Wangcaixuan (Rosa). 2018. "What Can One Learn in Gamelan Ensemble in One Semester? A Performative Ethnography of a World Music Ensemble." SEM Student News 14 (2): 28-31.

\begin{abstract}
Recent debates about bluegrass music's place in higher education have highlighted anxieties about the historic role that institutions of higher education have played in cultural colonization, erosion, and destruction. Using examples from the bluegrass band at a large Appalachian public university, this essay considers how the "bluegrass jam" might facilitate meaningful conversations about identity in a region subjected to colonial-style extraction for nearly three centuries. At the same time, this article problematizes the nature of the university's simultaneous support of regional culture and the propagation of resource extraction and environmental decay.
\end{abstract}

\title{
RÉSUMÉ
}

Les récentes discussions sur la place de la musique bluegrass dans l'enseignement supérieur ont soulevé des inquiétudes quant au rôle historique que les établissements d'enseignement supérieur ont joué dans la colonisation, l'érosion et la destruction culturelles. Prenant pour exemple le groupe de bluegrass d'une grande université publique des Appalaches, cet essai examine comment le «bluegrass jam » pourrait faciliter des conversations utiles sur l'identité dans une région soumise à l'ascendance du style colonial depuis près de trois siècles. En même temps, cet article problématise la nature du soutien simultané de l'université à la culture régionale et à la propagation de l'extraction des ressources ainsi que de la dégradation de l'environnement.

\section{BIOGRAPHIES}

Travis D. Stimeling is associate professor of musicology at West Virginia University and director of the WVU Bluegrass and Old-Time Bands.

Sophia M. Enriquez is pursuing a doctoral degree in ethnomusicology with specializations in folklore and women, gender, and sexuality studies at the Ohio State University. Her research explores Latinx music and identity in Appalachia. While a student at West Virginia University, she performed with the WVU Bluegrass and OldTime Bands. 